\title{
VÖRÖS TÖLGYESEK TERMÉSZETES FELÚJÍTÁSA ÉS ERDÖNEVELÉSE: ESETTANULMÁNYOK
}

\author{
Keserü Zsolt, Csiha Imre, Kovács Csaba, Rásó János és Rédei Károly \\ NAIK Erdészeti Tudományos Intézet
}

\begin{abstract}
Kivonat
A vörös tölgyet (Quercus rubra), a legelterjedtebb idegenhonos tölgyfajunkat több, mint 100 éve termesztik állományban hazánkban. Gyors növekedése, nagy fatérfogat hozama, értékes faanyaga következtében a nemesnyárak és az akác mellett a legfontosabb exóta fafajunk. A vörös tölgyesekben alkalmazható természetes felújitási iránytechnológiák változatait a fahasználati vágásmódokhoz és a hozzájuk tartozó természetes felújitási lehetőségekhez igazodóan kell kialakítani. A vizsgált fafaj esetében a tarvágás jellegü felújitóvágás, illetve a fokozatos felújitás alkalmazására van reális, a gyakorlat számára is ajánlható lehetőség.
\end{abstract}

Kulcsszavak: vörös tölgy, Quercus rubra, természetes felújitás, vágásmód.

\section{NATURAL REGENERATION OF RED OAK (QUERCUS RUBRA) STANDS: CASE STUDIES}

\begin{abstract}
In Hungary, the red oak (Quercus rubra), the most widespread non-native oak has been grown in forests for more than 100 years. Due to its fast growth, high yield and valuable timber material it is the most important exotic tree species besides the hybrid poplars and black locust. The variations of the natural regeneration technologies applicable in red oak stands should be developed according to the main felling methods and the associated natural regeneration possibilities. In the case of red oak stands the application of clear cutting-like regeneration cutting and shelterwood cutting can be recommended for the practice.
\end{abstract}

Keywords: red oak, Quercus rubra, natural regeneration, regeneration technologies.

\section{BEVEZETÉS}

A vörös tölgy (Quercus rubra Linnaeus, 1753) a nemes nyárak és az akác után a legjelentősebb egzóta fafajunk. Közel 300 évvel ezelőtt hozták be Észak-Amerikából Európába, ahol erdőgazdasági jelentőségét korán felismerték. Hazánkban első telepitéseinek kivitelezésére a múlt század első évtizedeiben került sor, majd az 1960-as években telepítése újabb 
lendületet kapott (Birck 1962). A magyarországi vörös tölgyesek területe ez idő szerint megközelítőleg 16.000 hektár. Európában, Németországban 44.000, Franciaországban 43.000, Spanyolországban 20.000, Lengyelországban 15.000, Bulgáriában 11.300, Hollandiában 8.700 , Romániában 2.500 , Belgiumban pedig 1.600 hektáron tenyésznek vörös tölgyesek (Hasenauer 2016).

A vörös tölgy erdeink produktivitásának emelésére alkalmas fafaj, amelyet nagy vitalitása, széles ökológiai toleranciája és a különböző kárositásokkal szembeni kiváló ellenállóképessége alapoz meg (Rédei et al. 2011). Mindezek ismeretében a NAIK Erdészeti Tudományos Intézet hosszabb ideje folytat a vörös tölgyesek termesztésfejlesztéséhez kapcsolódó $\mathrm{K}+\mathrm{F}+\mathrm{I}$ tevékenységet a fafaj egyik legjelentősebb termesztési körzetében, a Nyírségben.

Jelen tanulmányunk legföbb célja, hogy a fentebb említett újabb kutatás-fejlesztési eredmények felhasználásával segítse a vörös tölgy - indokolt ökológiai feltételek melletti - további elterjesztését, ezzel is növelve erdeink jövedelemtermelő képességét. A vörös tölgy termesztéstechnológiai fejlesztése azonban továbbra sem nélkülözheti a helyi szakemberek tapasztalatainak megismerését s azok hasznosithatóságát.

\section{A vörös tölgy fontosabb erdőművelési tulajdonságai}

A vörös tölgyet, a legelterjedtebb idegenhonos tölgyfajunkat több, mint 100 éve termesztik hazánkban. Kedvező fatermési és erdőművelési tulajdonságainak köszönhetően napjainkban az összes erdőterület kb.0,8 \%-án tenyészik. Főbb elterjedési területei a Dél- és Délnyugat-Dunántúl (Baranya, Somogy és Zala megyék), valamint a Nyírség (Rédei 2010).

Telepítésével erdeink fafajválasztéka bővíthető. Gyors növekedése, nagy fatérfogat hozama, értékes faanyaga révén a nemesnyárak és az akác mellett a legfontosabb, viszonylag gyorsan növő exóta fafajunk. Elönyös tulajdonsága, hogy nincs olyan kárositója, amely jelentős növedékveszteséget okozna. Vitalitása nagy, gyakran terem, jól újul. Csemetenevelése könnyü, az átültetést jól türi, fiatalkori gyors növekedése miatt kevés ápolást kíván. Rontott erdeink átalakitása során jelentősebb szerepe is lehet (Rédei et al. 2007).

Kedvező vízgazdálkodású, levegős és mészmentes talajon gyors növekedésü. Megél az Alföld 500 mm-es átlagos évi csapadékmennyiségü tájain, de ugyanakkor jó növekedést mutat a Dunántúl $750-800$ mm csapadékmennyiséget meghaladó termőhelyein is. Optimális növekedését nálunk savanyú homokok réti erdőtalaján éri el, ahol a talajvíz mozgó és nincs túl mélyen. Jó növekedést mutat a rozsdabarna erdőtalajon, a kovárványos barna erdőtalajon, valamint a mély termőrétegü agyagbemosódásos barna erdőtalajon (Keresztesi, 1967).

A vörös tölgy igen bő avart képez, legtöbbet az erdei fafajok közül. Fiatalon erösen árnytűrő, később fényigényes. Gyorsan nő, faállományában kiválóan differenciálódik. Zárt koronája nemcsak a vertikális, de a horizontális záródást is lehetővé teszi. Visszaszerző képessége is kiváló. Jól sarjadzik, még faállománya alatt is kihajtanak a kivágott fák tuskói, és cserjeszerüen borítják az erdő alját. A zöldnyesést is bírja. 
Változatai közül a nagy makkú vörös tölgy (Qu. rubra L. var. maxima (Marsh) Sarg. 1916) érdemel emlitést, mert a vörös tölgy faállományaiból ez foglalja el a legnagyobb területet. Levele, makkja nagyobb, mint a főalaké, amelyre a botanikai leírás vonatkozik. Az árterek keményfás erdeiben elegyithető a sártölgy (var. palustris (Münchh.) Kuntze, 1891). A meglévő vörös tölgyesekben elegyként gyakran fordul elő a bíbortölgy (var. coccinea Münchh. 1770).

Mint idegenföldi, honosított fafajnak Magyarországon nincsenek sem természetes, sem természetszerű előfordulásai, erdőallományai, ezért a magyarországi vörös tölgyesek biológiai - ökológiai megítélésük alapján a kultúrerdök csoportjába sorolhatók. Ebböl következően müvelésükre (a fatermesztés technológiájára) is elsősorban az ültetvényszerü fatermesztés feltételrendszere a jellemző.

\section{A vörös tölgy makk csírázásának ökológiai feltételei}

A vörös tölgy korán kezd virágozni és teremni. Szabad állásban 20, állományban 25 éves korától terem. Szórványtermése minden évben megfigyelhető, és bőven is gyakrabban terem, mint az őshonos tölgyek. A szabad állásban lévő fák feltűnően gyakran és bőségesen teremnek. Mintegy 10 nappal később fakad, mint a korán fakadó kocsányos tölgy. Tavaszi hajtásképzése erőteljes és hosszan tartó. Másodhajtás képzése nem jelentős, bár a fiatal fák kedvező időjárás esetén nyári hajtásokat is hoznak. Levelét ősszel korán leveti. A lombosodással egy időben virágzik, termésfejlődése 14 hónapig tart. Makkja tavasszal csírázik.

A vörös tölgy magtermését befolyásoló legfontosabb tényezők: a magtermő fák kora, egyéni, örökletes tulajdonsága, a fák egészségi állapota, a korona fejlettsége és helyzete a faállományban, a termőhely hatása (tengerszint feletti magasság, kitettség, a talaj állapota, vízgazdálkodása, esetleges előnytelen domborzati viszonyok, pl. fagyzug stb.), abiotikus és biotikus kárositások, erdőművelési (erdőnevelési) mód. Végül fontos környezeti feltétel a talajfelszín kellö porhanyóssága is, hogy a csíra gyököcskéje behatolhasson a talajba.

A vörös tölgy makk csírázása szempontjából, hasonlóan más fafajok terméséhez, a legjelentösebb környezeti tényező a talaj- és légnedvesség, amely a makk víztartalmát és a csírázás vízgazdálkodását befolyásolja. A tölgymakk igen érzékenyen reagál víztartalmának kisebb mértékű csökkenésére is. Ez nemcsak a csírázás megindulásának lehetőségét, illetve csiraképességének elvesztését befolyásolja, hanem víztartalom csökkenés arányában romlik csiraképessége is. Eltolódik a csírázás megindulásának időpontja és változik fagyérzékenysége, mivel a tölgymakk víztartalma és fagyérzékenysége között szoros összefüggés van.

A vörös tölgy csírázásökológiájával kapcsolatos legfontosabb ismérveket Nemky (1964) és Suszka et al. (2008) alapján a következökben foglaljuk össze. A vörös tölgy makkja teljesen átfekvő, és ezért a természetben csak tavasszal csírázik. Átfekvési ideje átlagosan 6-8 hét. Amennyiben a makk víztartalma 18-20\% alá esik, akkor elvész annak csíraképessége. Ez az érték valamivel alacsonyabb, mint az őshonos tölgyeknél tapasztalt 25-28\%-os érték, 
ami azt mutatja, hogy a vörös tölgy makkja valamivel ellenállóbb a szárazsággal szemben. Ahhoz, hogy a makk csírázási százaléka legalább 70\%-os legyen, víztartalmának el kell érnie a 35\%-ot. A makk nedvességtartalma és fagyérzékenysége közötti összefüggés-vizsgálatok azt mutatták, hogy a vörös tölgy esetében 37-70\%-os víztartalom mellett tapasztalták a legkisebb mértékű fagykárosodást. $A-17 C^{\circ}$-ra való 24 órás lehűtést a tölgyfajok közül már csak a vörös tölgy viselte el részben.

A vörös tölgy mintegy 10 nappal később fakad, mint a kocsányos tölgy. A lombosodással egyidőben virágzik, termésfejlődése 14 hónapig tart. Makkja tavasszal csírázik.

\section{A VIZSGÁLATOK HELYE ÉS MÓDSZERE}

A vörös tölgy jól újul, gyakran már a 30-40 éves állományok alatt bőséges újulat van. Ezt bizonyítják a Nyírerdő Zrt. Debreceni és Nyírbátori Erdészetének területén lévő, összesen 16 vörös tölgyesben kijelölt mintaparcellákon történő újulatfelvételi vizsgálatok is (Rédei et al. 2010) (1. és 2. ábra).

A vizsgált erdőrészletekben $20 \times 25$ m-es mintaparcellákat, azon belül pedig $6 \times 8$ m-es precíz parcellákat tüztünk ki, ahol a vörös tölgy újulat, illetve az ott található $1 \mathrm{~m}$-es magasságot meg nem haladó fásszárúak felvételére került sor, az ERTI-ben kidolgozott metodika alapján (1. táblázat). A mintaparcellákon részletes faállomány-szerkezeti és fatermési elemzéseket is végeztünk. let:

A kor ( $x$, év) és az 1 hektáron talált újulatszám ( $y$, db/ha) közötti összefüggést leíró egyen-

$$
y=-105697+7476 x, r=0,799
$$

A 40 és 59 év közötti, 5 éves intervallumonkénti, 1 hektáron található újulatszám a fenti összefüggés alapján a következő:

- 40 éves korban $193343 \mathrm{db} / \mathrm{ha}$,

- 45 éves korban $230723 \mathrm{db} / \mathrm{ha}$,

- 50 éves korban $268103 \mathrm{db} / \mathrm{ha}$,

- 55 éves korban $305483 \mathrm{db} / \mathrm{ha}$,

- 59 éves korban $335387 \mathrm{db} / \mathrm{ha}$.

A közölt összefüggés az adott tájban tenyésző vörös tölgyesek természetes felújitásához nyújt adatszerü információt. A kor-függő újulatszám megléte ugyanis alapfeltétele az eredményes természetes felújitás megvalósításának. Ez utóbbi ütemezésére vonatkozóan a később közölt erdőnevelési modell nyújt eligazítást. 
1. táblázat: Vörös tölgyesek újulatfelvételi adatai.

Table 1: Data of regrowth survey of red oak stands.

\begin{tabular}{|c|c|c|c|c|}
\hline $\begin{array}{c}\text { Sor- } \\
\text { szám }\end{array}$ & $\begin{array}{c}\text { Helység, tag, erdő- } \\
\text { részlet }\end{array}$ & $\begin{array}{c}\text { Kor } \\
\text { (év) }\end{array}$ & Termőhelytípus & $\begin{array}{c}\text { Újulat száma } \\
\text { (db/ha) }\end{array}$ \\
\hline 1. & Debrecen 205D & 27 & KTT, VFLEN, KBE, MÉLY & 106.650 \\
\hline 2. & Kömörő 8D & 30 & KTT, IDÖSZ, R, KMÉ & 217.776 \\
\hline 3. & Debrecen 226E & 31 & KTT, VFLEN, HH, KMÉ & 129.979 \\
\hline 4. & Debrecen 228A & 31 & KTT, VFLEN, HH, KMÉ & 138.311 \\
\hline 5. & Hajdúböszörmény 43F & 34 & KTT, VFLEN, HH, KMÉ & 97.068 \\
\hline 6. & Debrecen 297D & 35 & KTT, IDŐSZ, HH, KMÉ & 127.896 \\
\hline 7. & Debrecen 237E & 36 & KTT, IDŐSZ, HH, MÉLY & 128.729 \\
\hline 8. & Kisszekeres 6l & 46 & KTT, IDÖSZ, R, MÉ & 198.224 \\
\hline 9. & Nyíregyháza 19A & 48 & KTT, VFLEN, HH, MÉLY & 133.520 \\
\hline 10. & Kisszekeres 6 G & 49 & KTT, IDÖSZ, RO, MÉLY & 237.120 \\
\hline 11. & Devecser 7B & 51 & KTT, IDÖSZ, R, KMÉ & 412.017 \\
\hline 12. & Nyírgelse 1C & 54 & KTT, IDÖSZ, KBE, KMÉ & 313.872 \\
\hline 13. & Nyírgelse 1 F & 54 & KTT, IDŐSZ, KBE, KMÉ & 356.512 \\
\hline 14. & Nyírgelse 2A & 54 & KTT, IDŐSZ, KBE, MÉLY & 256.464 \\
\hline 15. & Nyírgelse 2K & 54 & KTT, IDŐSZ, KBE, MÉLY & 280.176 \\
\hline 16. & Nyírbogát 4D & 59 & KTT, VFLEN, KBE, MÉLY & 355.680 \\
\hline
\end{tabular}

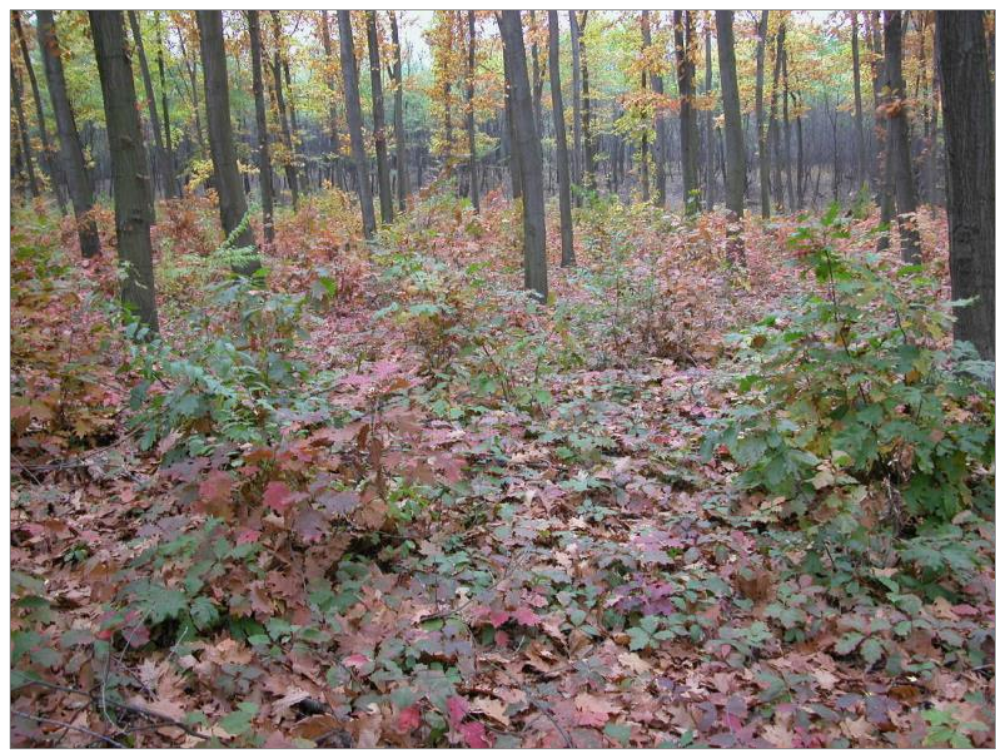

1. ábra: Vörös tölgy újulat Nyírgelse $2 K$ erdörészletben.

Figure 1: Red oak regrowth in the Nyírgelse $2 \mathrm{~K}$ subcompartment. 


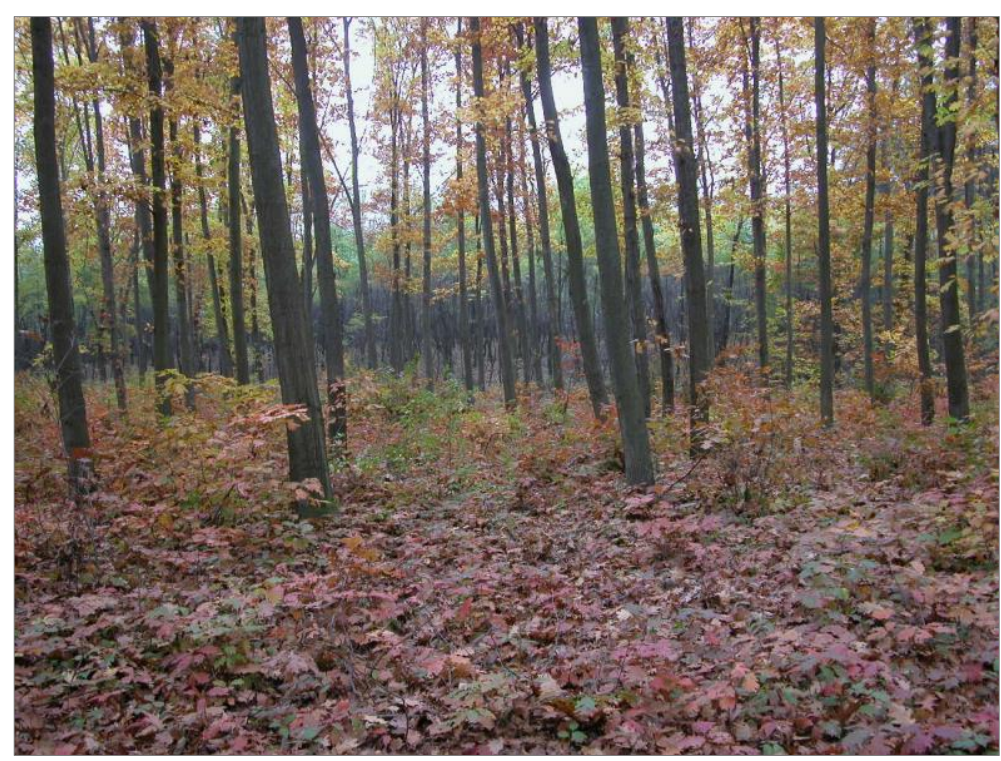

2. ábra: Vörös tölgy újulat Nyírbogát 4D erdörészletben.

Figure 2: Red oak regrowth in the Nyírbogát 4D subcompartment.

A 3. ábra a Debrecen $226 E$ erdőrészletben található vörös tölgyes faállomány-szerkezeti vizsgálatának egy fontos részterületét, a mellmagassági átmérő szerinti törzsszám-, illetve fatérfogat eloszlást ábrázolja. A természetes felújitás megtervezésekor az itt bemutatott elemzéseket minden esetben ajánlott elvégezni a lékek térbeni eloszlásának, illetve méretének meghatározása céljából.

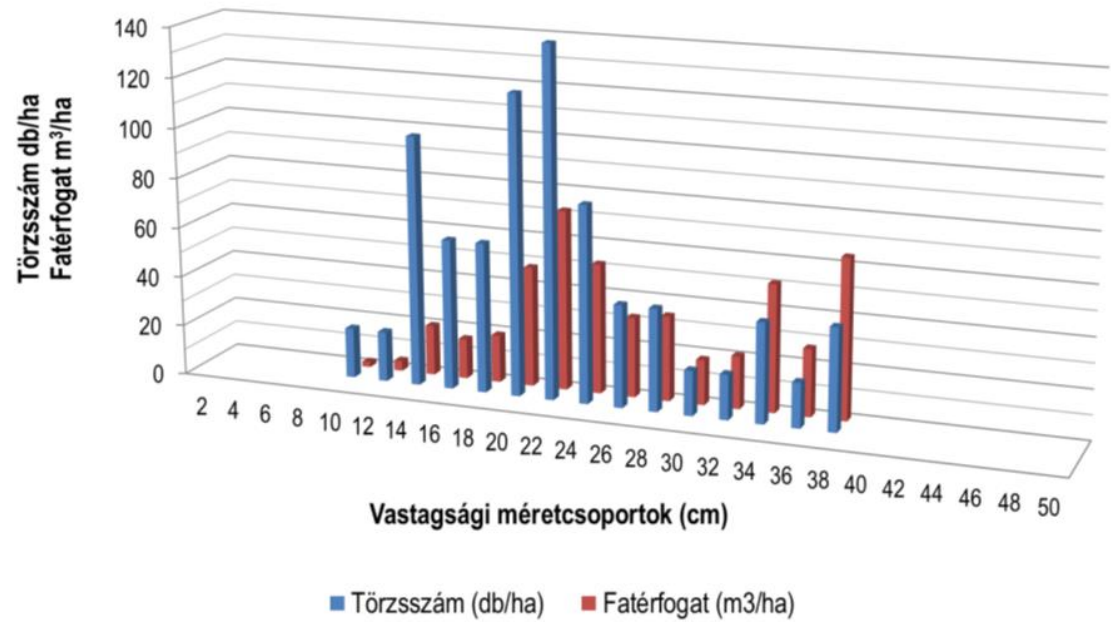

3. ábra: Vörös tölgy állomány hektáronkénti törzsszámának és hektáronkénti fatérfogatának átmérő méretcsoportok szerinti eloszlása (Debrecen 226E).

Figure 3: Distribution of stem number and volume of a red oak stand per hectare according to the diameter size classes (Debrecen 226E). 


\section{Vörös tölgyesek természetes felújításának gyakorlata}

A vörös tölgyesekben alkalmazható természetes felújitási iránytechnológiák változatait a főhasználati vágásmódokhoz és a hozzájuk tartozó természetes felújitási lehetőségekhez igazodóan kell kialakítani. A vizsgált fafaj esetében a tarvágás jellegủ felújítóvágás, illetve a fokozatos felújitás alkalmazására van reális, a gyakorlat számára is ajánlható lehetőség.

A tarvágás jellegű felújitóvágás alkalmazásával a vágásérett faállományt a már meglévő újulat fölül egy lépcsőben termeljük le. A tarvágás jellege egy lépcsőben - egy időben végrehajtott véghasználatból következik, de a „normál” tarvágástól a természetes újulat megléte különbözteti meg. Az erdőrészleten belül a tarvágást többféle módon, így időben fokozatosan egymás után következő sávokban és foltokban is végre lehet hajtani. A kivitelezés módja (formája) alapján lékes és kulisszás felújitóvágási módozatokat különítünk el. A fokozatos felújitóvágások közül tölgyesekben (beleértve a vörös tölgyeseket is) a többé-kevésbé egyenletes bontáson alapuló ernyős felújitóvágás felel meg leginkább. Ennek az az előfeltétele, hogy az adott erdőrészletben egyidőben olyan makktermés jelentkezzék, amelyből közel azonos fejlettségü újulat nevelhető fel az anyaállomány alatt. Az egyenletes újulat többé-kevésbé egyenletes záródásbontást, felszabadítást igényel. A felszabadító-vágások alkalmával a lábon álló fatérfogat $50-60 \%$-a termelhető ki, s a végvágásra marad a fatérfogat $40-50 \%$-a.

E módszer esetében a felújitás időtartama maximum 15 év, s az alábbi főbb müveleteket foglalja magába:

- véghasználat előtti teendők: cserje- és bozótirtás,

- a véghasználat tartama alatt elvégzendő feladatok: az anyaállomány záródásának megbontása, sarjleverés, irányított döntés,

- feladatok a végvágáskor: irányított döntés, kíméletes közelítés,

- pótlás: méretes csemetével, részleges talajelőkészitéssel, vagy talajelőkészités nélkül,

- ápolás: újulatápolás, sarjleverés,

- növényvédelem: szükség szerint (vadkárelháritó keritést is beleértve).

Az intenzív magassági növekedés befejeződésével - 25-40 éves kortól - erőteljes belenyúlás (növőtér-bővités) szükséges. Ekkorra már kialakultak azok a törzsek, melyek fenntartása a véghasználatig ésszerü (V-fák). Arra törekedjünk, hogy ezekre tevődjön át az erőteljes vastagsági növekedésböl származó növedék-többlet. A véghasználatig fenntartandó törzsek koronái részére kell ebben az időszakban a mindenkor megfelelő növőteret biztosítanunk. Ezért a felső koronaszintbe is bele kell nyúlnunk, hogy a jó koronaméretü faegyedek vastagodási képességüket tökéletesen kihasználhassák. A vágásérettségi kor elött a viszonylag kevés számú törzsböl összetevődő faállományban csak mérsékelt előhasználat gyakorolható, hogy a koronaszint ne váljék hézagossá. 
2. táblázat: Vörös tölgyesek erdőnevelési modellje (Nyírség,Rédei 2010 nyomán)

Table 2: Forest tending model for red oak stands (Nyírség)

\begin{tabular}{|c|c|c|c|c|c|c|}
\hline \multirow[b]{2}{*}{$\begin{array}{l}\text { A nevelővágások } \\
\text { elvégzésének } \\
\text { időpontja } \\
\text { kor (év) }\end{array}$} & \multicolumn{6}{|c|}{ A főállomány (nevelővágás utáni állapot) } \\
\hline & $\begin{array}{c}\text { átlagos } \\
\text { magassága }(\mathrm{H}) \\
(\mathrm{m})\end{array}$ & $\begin{array}{c}\text { átlagos } \\
\text { átmérője } \\
\left(D_{1,3}\right) \\
(\mathrm{cm})\end{array}$ & $\begin{array}{c}\text { fatérfogata } \\
\text { (V) } \\
\left(\mathrm{m}^{3} / \mathrm{ha}\right)\end{array}$ & $\begin{array}{c}\text { törzsszáma } \\
\text { (N) } \\
\text { (db/ha) }\end{array}$ & $\begin{array}{c}\text { körlap- } \\
\text { összege } \\
(\mathrm{G}) \\
\left(\mathrm{m}^{2} / \mathrm{ha}\right)\end{array}$ & $\begin{array}{c}\text { növőtér } \\
\text { (m²/fa) }\end{array}$ \\
\hline \multicolumn{7}{|c|}{ I. fatermési osztály } \\
\hline 10 & 9 & 7 & 50 & 2000 & 4,3 & 7,7 \\
\hline 20 & 16 & 14 & 140 & 930 & 9,3 & 14,3 \\
\hline 35 & 23 & 22 & 280 & 530 & 16,3 & 20,1 \\
\hline 50 & 27 & 29 & 370 & 400 & 21,7 & 26,4 \\
\hline 65 & 29 & 34 & 405 & 350 & 24,7 & 31,8 \\
\hline 80 & 31 & 37 & 505 & 340 & 25,5 & 36,6 \\
\hline \multicolumn{7}{|c|}{ II. fatermési osztály } \\
\hline 10 & 8 & 6 & 40 & 2200 & 3,9 & 6,2 \\
\hline 20 & 14 & 12 & 105 & 1100 & 7,9 & 12,4 \\
\hline 35 & 21 & 19 & 215 & 620 & 14,0 & 17,6 \\
\hline 50 & 25 & 26 & 315 & 480 & 18,0 & 25,5 \\
\hline 65 & 27 & 30 & 350 & 420 & 20,6 & 29,7 \\
\hline 80 & 29 & 33 & 445 & 400 & 21,7 & 34,2 \\
\hline \multicolumn{7}{|c|}{ III. fatermési osztály } \\
\hline 10 & 7 & 6 & 40 & 2500 & 3,5 & 7,1 \\
\hline 20 & 13 & 11 & 90 & 1200 & 7,2 & 11,4 \\
\hline 30 & 17 & 16 & 160 & 820 & 10,6 & 16,5 \\
\hline 45 & 21 & 21 & 240 & 600 & 14,4 & 20,8 \\
\hline 60 & 24 & 24 & 260 & 510 & 17,0 & 23,1 \\
\hline 75 & 26 & 26 & 330 & 460 & 18,8 & 24,4 \\
\hline \multicolumn{7}{|c|}{ IV. fatermési osztály } \\
\hline 10 & 6 & 5 & 30 & 2800 & 3,1 & 5,5 \\
\hline 20 & 12 & 10 & 80 & 1400 & 6,2 & 11.0 \\
\hline 30 & 15 & 14 & 120 & 970 & 8,9 & 14,9 \\
\hline 45 & 19 & 18 & 190 & 710 & 12,2 & 18,1 \\
\hline 60 & 21 & 20 & 200 & 610 & 14,2 & 19,2 \\
\hline 75 & 23 & 22 & 260 & 560 & 15,5 & 21,3 \\
\hline \multicolumn{7}{|c|}{ V. fatermési osztály } \\
\hline 10 & 6 & 5 & 30 & 3100 & 2,8 & 6,1 \\
\hline 20 & 10 & 8 & 55 & 1600 & 5,4 & 2,0 \\
\hline 35 & 15 & 13 & 115 & 1000 & 8,7 & 13,3 \\
\hline 50 & 17 & 16 & 135 & 800 & 10,8 & 16,1 \\
\hline 65 & 19 & 18 & 190 & 720 & 12,0 & 18,3 \\
\hline \multicolumn{7}{|c|}{ VI. fatermési osztály } \\
\hline 10 & 5 & 5 & 30 & 3600 & 2,4 & 7,1 \\
\hline 25 & 10 & 9 & 65 & 1600 & 5,4 & 10,2 \\
\hline 40 & 14 & 12 & 105 & 1100 & 7,9 & 12,4 \\
\hline 60 & 16 & 15 & 135 & 920 & 9,4 & 16,3 \\
\hline
\end{tabular}

Megjegyzés: Az első oszlop fatermési osztályok szerinti utolsó sorának kor-értékei a tervezhető vágásérettségi kor alsó határát mutatják, amelyek módositására - tekintettel a kevés számú véghasználati kort elért vörös tölgyesre - a helyi növekedési viszonyok, valamint a faállományok minőségi és egészségi állapota függvényében kerülhet sor. A 70 éven felüli adatsorok extrapoláltak. 
Hazánkban a 70 évnél idősebb vörös tölgyesek rendszeres fatermési vizsgálatára még alig volt mód. A rendelkezésre álló kevés számú fatermési (törzselemzési) adat azonban azt mutatja, hogy kedvező erdőművelési tulajdonságait kihasználva a vörös tölgy vágásérettségi korát a jobb termőhelyeken általában 80 évtől indulóan szabhatjuk meg.

A vörös tölgyesek természetes felújitásának tervezését és kivitelezésének ütemezését segíti a 2. táblázatban közölt erdőnevelési modell. A táblázat adatai a foállományra, vagyis az egyes tervezett nevelővágások utáni állományrészekre vonatkoznak. A modell a vörös tölgyesek várható hozamadatait is tartalmazza. A természetes felújithatóság (felújitás) tervezéséhez jó támpontot nyújtanak az egyes nevelővágások elvégzésének kor értékei. $A z$ utolsó tervezett belenyúlás időpontjának 15-20 évvel történő növelése adja a tervezett véghasználati kort. A fokozatos felújítóvágás időtartama az utolsó belenyúlás, illetve a véghasználati kor közé esik (Rédei et al. 2010).

Az erdőnevelési modell alapját képező fatermési tábla (Rédei et al. 2004) faállományszerkezeti alapösszefüggéseket leíró egyenletsorából e helyen csak egyet, de a faállománynevelés szempontjából kiemelten fontos összefüggést, a fỏállományra vonatkoztatott hektáronkénti törzsszám $(\mathrm{N})$ és a mellmagassági átmérő ( $\mathrm{D}_{1,3} \mathrm{~cm}$-ben) összefüggését leíró egyenletet közöljük:

$$
N=e^{9,8022 \theta-1,12607 n D_{1,3}}
$$

Az összefüggés alapján adott, vagy tervezett törzsszámhoz tartozó célátmérő, vagy adott célátmérőhöz tartozó törzsszám nagy biztonsággal adható meg. A vörös tölgyesekre kialakított fatermési és erdőnevelési kísérleti sorok értékelése, valamint a vonatkozó fatermési tábla (Rédei et al. 2004) alapösszefüggései alapján egy átlagos (III. fatermési osztályú) vörös tölgyest figyelembe véve két tisztitás, illetve tisztitóvágás (megközelitően 10 és 20 éves korban), egy törzskiválasztó gyérités (30 éves korban), illetve két növedékfokozó gyérités (45, illetve 60 éves korban) ajánlott, 75 éves korban tervezett végvágással.

\section{Vörös tölgyesek természetes felújítása Szlovákiában (esettanulmány)}

2009. október 27-én Dél-Szlovákiában (Ipolyság) a tárgykörhöz kapcsolódó tanulmányúton volt lehetöségünk részt venni, ahol újabb tapasztalatokat gyüjtöttünk a vörös tölgy természetes felújitásával kapcsolatban.

Az elsőként megtekintett terület egy 75 éves vörös tölgy állomány volt. Összefüggő tarvágást csak 1 ha-on engedélyeztek, ezért csoportos felújítóvágást alkalmaztak. A legjobb minőségű egyedeknek megfelelő növőteret biztosítottak, de fontos, hogy a törzsek ne kapjanak sok fényt, mert a vörös tölgy vízhajtás képzésére erősen hajlamos.

A kialakított lékek területe $300 \mathrm{~m}^{2}$ volt, és 1 ha-on átlagosan 8 léket találtunk. A vonatkozó mérések alapján az újulat száma kb. 300 ezer volt hektáronként, ami kb. 50 éves korra 800 
egyedre csökkent le. A kitermelésnél a fák töve a közelitő nyom irányába nézett, és darabolva, csörlővel húzták ki azokat, hogy a csemeték a legkevésbé károsodjanak. A sérült csemetéket eltávolították az egészséges egyedek zavartalan fejlődése érdekében.

A második bemutató terület egy 70 éves, gyengébb minőségű vörös tölgy állomány volt. 58 éves korban kezdték el az állomány lékes felújitását. A lékek állandó átmérője hozzávetőlegesen két famagasság volt. 2006-ban végezték az utolsó felújitó vágás és 12 éven belül teljesen letermelik majd az állományt. A területen hektáronként megközelítőleg 35 ezer újulatot regisztráltak. Az erős belenyúlás miatt a jobb minőségű fák is leromlottak. A silányabb talajrészeken már az 50 éves vörös tölgyek is kipusztultak vagy az egészségi állapotuk miatt ki kellett vágni azokat. A helyi szakemberek tapasztalatai alapján a szárazabb területeken 10-20 évvel rövidebb az élettartama a vörös tölgynek az átlagosnál. Véleményük szerint 2030 éves korra már kialakul a törzsek méreti és minőségi differenciálódása, valamint 20-25 éves kortól rendszeresen (5-7 évente) bele kell nyúlni az állományba a törzsminőség fokozása céljából. Kis területen kell bontani és a faegyedeket zárt állásban tartani a vízhajtások elkerülése végett.

\section{ÖSSZEFOGLALÁS}

A vörös tölgyesek termesztés-fejlesztésével összefüggő részfeladat központi témaköre a fafaj állományainak természetes úton (magról) történő felújithatóságának tudományos igényességü vizsgálata. Az újulat megjelenését, növekedését, az adott faállományon belüli térbeli elhelyezkedését több tényező (faállomány-szerkezet, mikro-ökológiai viszonyok, nevelővágások hatása, stb.) befolyásolja. $E$ témakörben megelőző kutatási eredmények ténylegesen nem állnak rendelkezésre, így minden, az elkövetkező években elvégzendő összefüggés-vizsgálat, illetve azok eredményei újszerüek lesznek mind az erdészettudomány, mind pedig a gyakorlat számára is.

A tárgykörhöz kapcsolódó $\mathrm{K}+\mathrm{F}$ munka abban a tekintetben is újszerü és egyedülálló hazánkban, hogy olyan termesztés-technológia kidolgozását tűzte ki célul, amely mindeddig csak az őshonos fafajokra volt jellemző. A természetes felújitás alkalmazásának a jelentős költségmegtakarításon kívül - elmarad a talajelökészítés - számos ökológiai előnye is van. A talajelőkészités elmaradásával nem tömörödik a talaj, a tápanyagkészlete nem szegényedik, ezáltal a talaj széntartalma sem csökken, ami a klímaváltozás szempontjából nagy jelentőséggel bír.

A vörös tölgyesek természetes felújitásával kapcsolatosan igen kevés, szisztematikus vizsgálatokon alapuló eredménnyel rendelkezünk. A következő évek feladata lesz az előzőekben leírt technológiai ajánlások gyakorlati bevezetése, a szükséges korrekciók és tapasztalatok folyamatos és egyidejü beépitésével. 


\section{KÖSZÖNETNYILVÁNÍTÁS}

A Nyírségben tenyésző vörös tölgyesek termesztésfejlesztésével kapcsolatos kutató-fejlesztő munkához a Nyírerdő Zrt. nyújtott anyagi támogatást, amelyért a szerzők e helyen is köszönetüket fejezik ki.

\section{FELHASZNÁLT IRODALOM}

Birck O. 1962: Fatermési vizsgálatok vörös tölgyre. Erdészeti Kutatások 58(1-3): 261-311.

Hasenauer H. (ed.) 2016. Non-Native Tree Species for European Forests: Experiences, Risks and Opportunities. Country reports. COST Action FP1403. Vienna.

Keresztesi B. (szerk.) 1967: A tölgyek. Akadémiai Kiadó, Budapest.

Nemky E. 1964: A tölgymakk csírázásökológiááanak legfontosabb kérdései, mint a sikeres természetes felújítás alapjai. Az Erdő 13(12): 537-542.

Rédei K., Veperdi I. \& Csiha I. (2004): Vöröstölgyesek fatermése a Nyírség erdőgazdasági tájban. Erdészeti Kutatások 91: 51-60.

Rédei K., Veperdi I. \& Csiha I. 2007: Yield of Red Oak Stands in the Nyírség Forest Region (Eastern-Hungary). Silva Lusitana 15(1): 79-87.

Rédei K. 2010: Vöröstölgyesek termesztése. Agroinform Kiadó, Budapest.

Rédei K., Csiha I. \& Keserü Zs. 2011: Vöröstölgyesek nevelése. Erdészeti Lapok 146(11): 333-334.

Rédei K., Csiha I., Keserű Zs., Rásó J. \& Győri J. 2010: Management of red oak (Quercus rubra L.) stands in the Nyírség forest region (Eastern Hungary). Hungarian Agricultural Research 19(3): 13-17.

Suszka B., Muller C. \& Bonnet-Masimbert M. 2008: Az erdei lombos fák magjai a begyưitéstől a vetésig. Mezőgazda Kiadó, Budapest.

Érkezett: 2017. március 31.

Közlésre elfogadva: 2017. október 24. 